\title{
Procurement in Automotive Industry
}

\author{
Ionela-Roxana PUIU \\ Transilvania University of Brasov, Romania, ionela.puiu@unitbv.ro \\ Mircea BOȘCOIANU \\ Transilvania University of Brasov, Romania, mircea.boscoianu@unitbv.ro \\ Eugen- Silviu VRĂJITORU \\ Transilvania University of Brasov, Romania, mircea.boscoianu@unitbv.ro \\ Elena-Corina BOȘCOIANU \\ INCAS Bucharest, Romania, boscoianu.corina@incas.ro
}

\begin{abstract}
The automotive industry is certainly one of the largest and dominant industry in the world being highly dependent on supply chains management. Customer requirements and technological development are changing rapidly so the need of automation in supply chain management is unavoidable. Procurement in automotive industry it is a key process closed linked with product management and production. The transformation generated by industry 4.0 is pushing also procurement to next level of automation adding value chain truth cost reductions, transparency and smart contracts. Global semiconductors shortage generated disruption in automotive industry supplies chain management and high sales decreases with important profit loses. The study aim is to determine procurement best practice for sustainable and efficient supply chain. In future procurement department should play a fundamental part in innovation management by focusing on efficiency and automation of operation tasks including negotiations. It is recommended to have long term strategies regarding good relationship between tier suppliers and smart contracts with OEM.
\end{abstract}

\section{Keyword}

procurement, supply chain management, automotive industry, suppliers, OEM, industry 4.0

\section{Introduction}

The automotive industry is one of the most important segments by revenue in the world and top contributor to global economy. In 2019 were produce 91.7 million cars and on 2020 the Covid-19 pandemic caused a decrease of $16 \%$ and were produce only 77.6 million cars.

One car has around $28.000-30.000$ parts if we count all components down to the nuts and bolts, but now there are a lot of different car models, most of the cars are custom made as the customer wants, so each car is different and the variance of parts increased.

Due to the very rapid technological changes generated by final customer requirements, the need for research is essential for creating a climate of innovation and management development.

The procurement department focuses on negotiating, creating a long-term relationship with suppliers for automotive components, monitoring the supplier evaluation, in the same time cutting costs and finding less expensive solution to increase company profitability. Procurement is playing a strategic role and creating a competitive advantage.

The automotive industry was already facing a big crisis in 2020 due to COVID-19 pandemic and in 2021 sales decreased due to global crisis generated by lack of semiconductor and microcontrollers, the procurement department was highly affected and with current conditions the focus must be placed on speeding up the detailed study on the automotive industry and finding solutions to reduce losses.

Both crisis impacted the supply chain management department, first due to lockdown, each OEMs, Original Equipment Manufacturers, stopped their production and the stoppages came in chain for all automotive suppliers causing increases on inventory level and also pushing sub-suppliers for components to delay the orders and deliveries. Second drag due to shortages on semiconductors and microcontrollers, so it is evident that decisions in procurement impacted supply chain management. 
The automotive industry was highly affected by components allocation for semiconductors and unfortunately OEMs like Renault Group, Stellantis (Fiat, Peugeot-Citroën, Opel), Ford, VW and DaimlerBenz, planned production stoppages because of this shortages on raw materials. These disruptions in supply chain in automotive industry created huge decreases in sales and high loses in revenue.

In one day an OEM, can produce around 1.450 cars, this mean each minute a car will exit from production line. In automotive industry there are different TIER Suppliers that deliver to OEM's:

- Tier 1 Supplier: Companies that supply OEM's with components and semi-manufactured goods;

- Tier 2 supplier: Companies that supply tier one suppliers which are the ones that supply directly OEM's;

- Tier 3 supplier: Companies that supply parts, sub-components to Tier 2.

We can consider that in Fig.1 all are suppliers, including the OEM that is supplier for final customer, of course the level of business is different and the OEM is giving the directions based on market requirements. The pressure is coming from the top to bottom level to reduce costs and provide high value. Still the OEMs depend on all TIER suppliers as suppliers depend on OEMs.

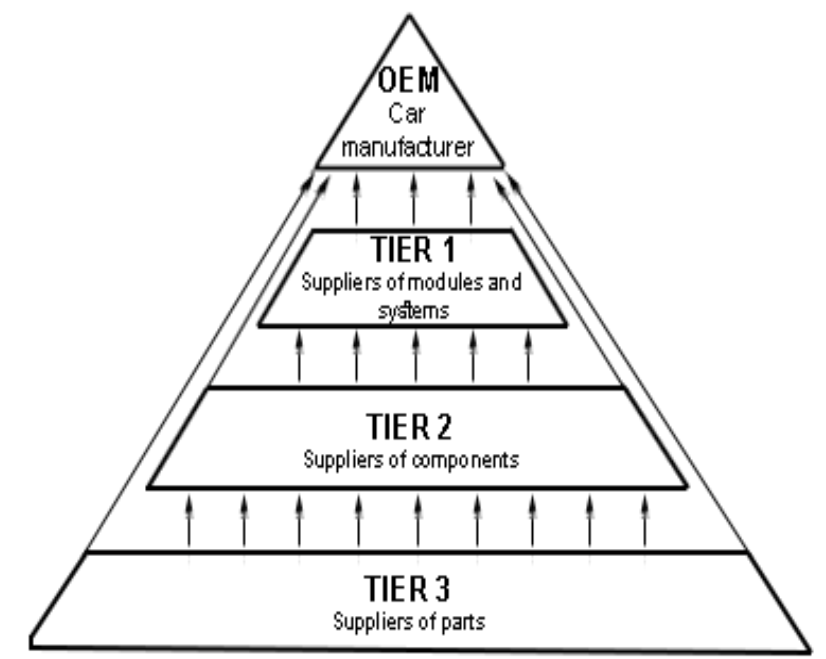

Fig. 1. Automotive supply chain - Supplier pyramid [4]

The OEMs must work with all TIER suppliers in long-term collaboration for improving the responsiveness, product quality and reducing the costs.

\section{Supply Chain Management - Process Flow Description}

Automotive industry has a high rate of fluctuation on demands and volumes, the forecast is for a longer period in comparison with other industries. Due to this frequent demand changes the procurement department has high challenges to bring all components in time to keep the production plan scheduled, to have the right quantity in order not to stop the production or deliveries to clients and the right price not to influence the cost of the finished goods.

In automotive industry the competition is intense, facing challenges like quality concerns, supplier and complex markets, plus the pressure to achieve profits.

Technology is changing fast and the market demand accelerate for next generation mobility, hybrid and electric vehicles which is forcing automotive manufacturers to re-think business models and strategies. Main materials used in automotive industry are steel, plastics, rubber, aluminium, copper, glass, still with the new trend more and more electronic components are used in automobiles. From these categories all components are split in commodities to be easier to negotiate the prices.

The challenging part of business management is to understand the complexity of supply chain operations in a global economy. The complexity increased for all supply chains because of global sourcing, long list of suppliers, fix frozen zone and long lead times and customer demand fluctuations that made the risk of disruption enlarged. 
Figure 2 represents the supply chain management process for a tier 1 supplier. The demands are coming from OEMs, preferable via EDI/WebEDI directly in supplier ERP system with a forecast of minimum six months, if not the orders are introduced in ERP system manually. Customer logistics will run the MRP (Material requirements planning) in order to schedule the quantities as customer requires.

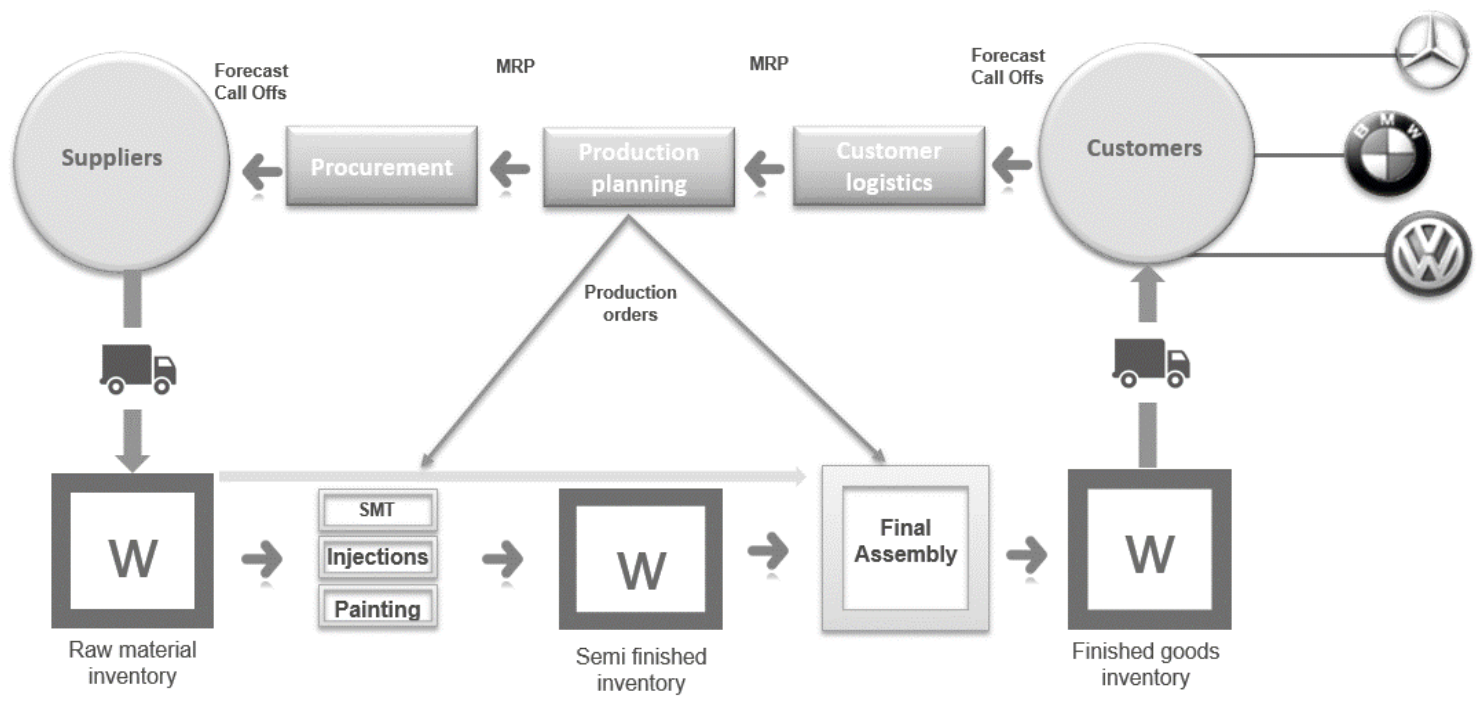

Fig. 2. Supply Chain Management process

The production is planned based on capacity of the production lines and the demand is converted in purchase orders or scheduling agreements that are sent to suppliers also preferable via EDI/WebEDI.

Suppliers receive purchase orders or delivery plans with a forecast for 12-18 months, they must confirm and deliver quantities as requested taking in consideration the production and transit lead time.

\section{Future in Procurement}

In any industry is preferred to have a good relationship with a supplier, in automotive industry is very important to establish a long-term relationship with a good communication and support from both parts especially because once a component is sourced at the beginning of the project usually will not be changed without final client approval. Collaborate closely with suppliers will add more value to the company taking in consideration a car model is sold on market at least 5 years.

A new strategy that should be implemented in automotive is to have for one component at least two different sources, two different suppliers. Right now due to safety reasons only one supplier is set and approved by OEM and the risk is high if the supplier will enter in insolvency or if a natural disaster will occur.

Another strategy applied in procurement is to automatize the process and eliminate manual work and human errors. As an example we can take the implementation of scheduling agreements instead of purchase orders. A purchase order (PO) is a one-time document agreement and is needed manual adding for vendor, quantity, delivery date and price. A scheduling agreement (SA) is a long-term agreement that can be maintain easier by running the MRP and adding automatically the predetermined conditions. A long term agreement with a vendor will enable him to negotiate more favourable conditions as obtaining a better price on materials, reducing the tariffs for transports and for this will benefit also the client. With a scheduling agreement the stock can be maintain at minimum level because the supplier will have the forecast at least for 12 months and with a good production plan can deliver as the customer requests. The digital technology improves the transparency in supply chain connecting the supplier with customer in real time, reducing the workload and increasing the performance.

In automotive to keep the stock level at minimum it is very important and in the same time it is difficult to achieve the inventory KPIs, so it is preferable to implement below sourcing models to reduce the stock value:

- Vendor Managed Inventory (VMI) consignment warehouse 
- Customer Managed Inventory (CMI) consignment warehouse

- Just-in-Time (JIT) - it is used for high runners, horizon for JIT is shorter, max 1 month and stock that must cover the demand for 1-2 days otherwise the JIT can be unprofitable.

For these three source models the communication is essential. The supplier must have access to information provided by client in different ways as orders, delivery plans, reports and access to client stock. Both parts must have an ERP system and able to work with scheduling agreements, transmission via EDI/Web EDI, ASN (advanced shipping notification) to be able to create shipping notification (ShipNt) in client ERP System. In this way the order process can be reduced and the information between client and supplier is automatized and eliminate manual work and errors.

As strategic sourcing it is advantageous to reduce the number of vendors and to have for critical parts also a second source. To consolidate the volume between less suppliers, to cut down the number of parts driving to cost efficiency and use same parts on more projects.

\section{Conclusions and Contributions}

Procurement has the opportunity to add value for the business, digitalisation will transform supply chains developing the agility that will improve the ability to respond rapidly to fast changes in market and customer demands reducing the disruptions. Industry 4.0 request for procurement a good communication and collaboration between all parties using the technology of ERP systems to communicate from supplier system to client system and reducing the traditional communication.

The automation of procurement processes will enable human resources to focus on strategic initiatives and cost reductions not only increasing efficiency but also improving profitability.

Further research is needed to identify other strategies and factors that could be more effectiveness. In conclusion any company should focus to improve procurement process to generate value by using at full potential the information technology and ERP system to achieve flexibility and increase responsiveness.

\section{References}

1. Mena C., van Hoek R., Christopher M. (2021): Leading Procurement Strategy. Driving Value through the Supply Chain. Kogan Page, ISBN 978-1398601604

2. Wu Y. (2019): Achieving Supply Chain Agility. Information System Integration in the Chinese Automotive Industry. Palgrave Macmillan, ISBN 9783319984407

3. Gurnani H., Mehrotra A., Ray S. (Eds.) (2021): Supply Chain Disruptions: Theory and Practice of Managing Risk. Springer London, ISBN 9780857297778

4. Bey N. (2019): Future Technology Photonics - Is the Product Development Ready for Automotive? PhotonicsViews, ISSN 2626-1308, Vol. 4/2019, pp. 44-48, https://onlinelibrary.wiley.com/doi/pdf/10.1002/phvs.201900032

5. Poluha R.G. (2016): The Quintessence of Supply Chain Management. Springer, ISBN 9783662485156

6. Kildow B.A. (2011): A supply chain management. Guide to business continuity. AMACOM, ISBN 978-0-8144-1645

7. Stadtler H., Kilger C., Meyr H. (2015): Supply Chain Management and Advanced Planning: Concepts, Models, Software, and Case Studies. Springer, 5th edition, ISBN 978-3642553097

8. Vrajitoru E.S., Boscoianu M., Boscoianu E.C. (2021): Aligning Complementary Funding Opportunities - through TAS - the Smart Answer to the Challenges of Industry 4.0 Transformation. Recent, ISSN 1582-0246, Vol. 22, no. 1(63), pp.50-54, https://www.recentonline.ro/2021/063/Vrajitoru-R63.pdf

9. Kauppila O., Välikangas K., Majava J. (2020): Improving supply chain transparency between a manufacturer and suppliers: a triadic case study. Management and Production Engineering Review, ISSN 2080-8208, Vol 11 (2021), no. 3, pp. 84-91, https://journals.pan.pl/dlibra/publication/134935/edition/117942/content, DOI: $10.24425 /$ mper.2020.134935

10. Liang Z., Art Chaovalitwongse W., Shi L. (2015): Supply Chain Management and Logistics: Innovative Strategies and Practical Solution. CRC Press, ISBN 978-1466577879

11. Gobetto M. (2014): Operations Management in Automotive Industries: From Industrial Strategies to Production Resources Management, Through the Industrialization Process and Supply Chain to Pursue Value Creation. Springer, ISBN 978-94-007-7593-0

12. Smith R. (2002): Global Supply Chain Performance and Risk Optimization: The Value of Real Options Flexibility Demonstrated in the Global Automotive Industry. Deutscher Universitätsverlag, ISBN 9783322814074

13. Díaz L.M. (2006): Evaluation of Cooperative Planning in Supply Chains: An Empirical Approach of the European Automotive Industry. Deutscher Universitätsverlag, ISBN 978-3-8350-5714-2 
14. Fornasiero R., Sardesai S., Barros A.C., Matopoulos A. (Eds) (2021): Next Generation Supply Chains: A Roadmap for Research and Innovation. Springer, ISBN 978-3030635046

15. Bozarth, C.C., Handfield R.B. (2019): Introduction to Operations and Supply Chain Management. Pearson, 5th edition, ISBN 978-1292291581

16. Geunes J., Pardalos P.M., Romeijn H.E. (2010): Supply Chain Management Models Applications and Research Directions. Springer, ISBN 978-1441952110

17. Booth C. (2010): Strategic Procurement: Organizing Suppliers and Supply Chains for Competitive Advantage. Kogan Page, ISBN 978-0749460228

18. Dolgui A., Proth J.-M. (2010): Supply Chain Engineering: Useful Methods and Technique. Springer, ISBN 9781849960168

19. ***: https://www.oica.net/production-statistics/ Accessed: 2021-09-15

20. Min H. (2015): The Essentials of Supply Chain Management: New Business Concepts and Applications. Pearson FT Press, ISBN 978-0134036236

21. Boscoianu M., Prelipcean G., Lupan M. (2018): Innovation enterprise as a vehicle for sustainable development A general framework for the design of typical strategies based on enterprise systems engineering, dynamic capabilities, and option thinking. Journal of Cleaner Production, ISSN 0959-6526, Vol. 172, pp. 3498-3507, https://doi.org/10.1016/j.jclepro.2017.06.120

22. Prelipcean G., Boscoianu M. (2020): Risk Analysis of a Hedge Fund Oriented on Sustainable and Responsible Investments for Emerging Markets. Amfiteatru Economic, ISSN 1582-9146, eISSN 2247-9104, Vol. 22, no. 55, pp.653-667, DOI:10.24818/EA/2020/55/653, https://www.amfiteatrueconomic.ro/temp/Article 2923.pdf

23. Prelipcean G., Boscoianu M., Lupan M. (2014): Innovative Financing Solutions Based on Venture Capital and Private Equity to Support the Development of Entrepreneurship in Romania. Transformation in Business and Economics, ISSN 1648-4460, Vol. 13, no. 3C, pp. 331-347 